\title{
Influence of Different Planting Dates on Growth, Yield and Quality of Menthol Mint (Mentha arvensis L.) Cultivars during Kharif Season
}

\author{
Shwetha Desai $^{3 *}$, T.N. Pushpa ${ }^{3}$, D. Srikantaprasad ${ }^{3}$, V. Kantharaju ${ }^{1}$, \\ I.B. Biradar ${ }^{2}$ and J.S. Hiremath ${ }^{3}$
}

${ }^{I}$ Department of Pathology and Head (AICRP Tropical Fruits), K. R. C. College of

Horticulture, Arabhavi-591 218, University of Horticultural Sciences, Bagalkot-587 102, Karnataka, India

${ }^{2}$ Department of Agronomy, K. R. C. College of Horticulture, Arabhavi-591 218, University

of Horticultural Sciences, Bagalkot - 587 102, Karnataka, India

${ }^{3}$ Department of Plantation, Spices, Medicinal and Aromatic Crops, K. R. C. College of

Horticulture, Arabhavi-591 218, University of Horticultural Sciences, Bagalkot-587 102, Karnataka, India

*Corresponding author

\begin{abstract}
A B S T R A C T
Keywords

Menthol mint,

Planting dates,

Cultivar, Net

returns, $\mathrm{B}$ : $\mathrm{C}$ ratio

Article Info

Accepted:

07 May 2019

Available Online:

10 June 2019

The investigation on menthol mint cultivars Kosi, Kushal, Sambhav, Saksham and Himalaya was carried out to study the effect of different planting dates $\left(5^{\text {th }} \mathrm{July}, 20^{\text {th }} \mathrm{July}\right.$ and $5^{\text {th }}$ August) in kharif 2017-18 on growth, yield and quality in split plot design with three replications under Northern dry zone of Karnataka. The results revealed that, irrespective of cultivars, planting on $5^{\text {th }}$ July was better with the highest values for average plant height, spread, number of branches, leaf area and total dry matter accumulation, resulting in the highest fresh and shade dried herbage yield (15.76 and $11.90 \mathrm{t} / \mathrm{ha}$, respectively) along with the highest essential oil content $(0.79 \%)$ and essential oil yield (95.44 kg/ha). Among different cultivars cv. Sambhav recorded maximum plant spread and number of branches, leaf area and total dry matter accumulation, fresh and shade dried herbage yield (13.53 and $11.10 \mathrm{t} / \mathrm{ha})$ and essential oil content $(0.78)$ providing the highest essential oil yield $(88.48 \mathrm{~kg} / \mathrm{ha})$ with the maximum menthol content $(72.06 \%)$. Sambhav planted on $5^{\text {th }}$ July resulted in the maximum net returns $\left(\square 93,227\right.$ ha $^{-1}$ ) with a B: C ratio of 2.76 .
\end{abstract}

\section{Introduction}

Mints belong to the genus Mentha have been known to man for a long time and are used in all continents of the world. These are the main source of aroma compounds such as menthol, carvone, linalool and linalyl acetate used widely in food, cosmetic and pharmaceutical preparations. The commercial cultivation of mints as a source of essential oils is relatively recent development. Because of the suitability of agro-climate and soil for mint cultivation 
as an annual crop, India has become the major supplier of menthol mint oil to the international market. However, menthol mint remains the principal cultivated mint in India (Varshney, 2011). Menthol mint is valuable commercially because of its high oil yield and the menthol content. Leaves and stems are known to contain about 0.6 per cent oil which has 70-85 per cent menthol in it.

The geographical areas of India, where all the rice, wheat, potato and sugarcane crops can be cultivated, are suitable for mint farming also. In India, it is commercially grown in subtropical plains as a summer season crop after the harvest of winter season crops viz., potato, mustard and pea etc. In Northern dry zone of Karnataka, not much research work has been carried out on menthol mint, there is a need for development of package of practices for its large scale cultivation for betterment of the farming community. Planting dates and cultivars are the major factors that influence the growth, development and yield of the crop. Indian monsoon is very erratic and uncertain. More than 70 per cent of the cultivated area of menthol mint in India is affected by early onset of monsoon (Singh, 2005 and Singh et al, 2008). Hence, the present research programme is planned to select the suitable planting date and cultivars for high herbage, essential oil yield in Northern dry zone of Karnataka.

\section{Materials and Methods}

The present investigation was carried out during 2017-2018 for kharif season in the Department of Plantation, Spices, Medicinal and Aromatic Crops, Kittur Rani Channamma College of Horticulture, Arabhavi, University of Horticultural Sciences, Bagalkot situated in northern dry zone (Zone No. 3; Region-2) of Karnataka at $16^{\circ} 15^{\prime} \mathrm{N}$ latitude and $74^{\circ} 45^{\prime} \mathrm{E}$ longitude, at an altitude of $612 \mathrm{~m}$ above mean sea level.
Arabhavi is considered to have the benefit of both south-west and north-east monsoons. During experiment, crop received about 359.6 $\mathrm{mm}$ of rainfall, (July - December 2017), the mean temperature and mean relative humidity (RH) ranged from $26.15^{\circ} \mathrm{C}$ and 91.10 per cent (July 2017) to $22.10^{\circ} \mathrm{C}$ and 78.00 per cent (December 2017), respectively. The soil of experimental site is sandy clay loam (vertisols) with alkaline $\mathrm{pH}$ (8.79).

\section{Experimental details}

The experiments were laid out in split-plot design with three replications, considering planting dates as main treatments $\left(5^{\text {th }} \mathrm{July}, 20^{\mathrm{th}}\right.$ July and $5^{\text {th }}$ August) and cultivars as sub treatments (Kosi, Kushal, Sambhav, Saksham and Himalaya).

The experimental site was brought to fine tilth by ploughing deeply with tractor drawn reversible double mouldboard plough. Then the plots of $3.6 \mathrm{~m}$ width and $4.5 \mathrm{~m}$ length were laid out and separated by bunds of 60 $\mathrm{cm}$ width as per the plan making provision for irrigation channels. The plants were uprooted and white stolons of uniform thickness were separated. They were cut into of 7.0 to10.0 $\mathrm{cm}$ long cuttings having 2-3 nodes and dipped in 0.3 per cent $\mathrm{COC}$ for $5-10$ minutes before planting. The furrows were opened at $45 \mathrm{~cm}$ interval in each plot. Prepared stolons were placed horizontally in mid of furrows at 30 $\mathrm{cm}$ spacing, at a depth of 2.5 to $4.0 \mathrm{~cm}$ and later covered with soil. Irrigation was given immediately after planting and subsequent irrigations were given at eight to ten days intervals depending on the rainfall and soil moisture. The crop was harvested at 120 days after planting when the crop was at fifty per cent flowering.

Observations on growth parameters like plant height, spread and number of branches and were recorded on five randomly selected 
plants in each replication of different treatments at and at harvest. The leaf area was calculated on five randomly selected plants by using Biovis instrument at harvest. For total dry matter accumulation, the selected five plants were uprooted from soil and the different plant parts like leaves, stem and roots were separated and dried in oven for 15 hrs at $60^{\circ} \mathrm{C}$. The average weight of leaves, stem and roots per plant was weighed on balance and expressed in grams. The fresh herbage yield was recorded in each plot at the time of harvest. Then fresh yield per hectare was calculated on the basis of fresh herbage yield per plot. The fresh herbage from net plot dried in shade for 3-4 hours. The shade dried herbage yield was calculated on the basis of shade dried herbage yield per plot. Known weight of fresh herbage from each plot was taken and withered for few hours in shade. The plant material was chopped into small pieces and essential oil extraction was done by hydro-steam distillation method using essential oil extraction unit of $10 \mathrm{~kg}$ capacity (CSIR - Institute of Himalayan Bioresource Technology patented technology). Essential oil content was estimated on shade dried weight and menthol content was estimated by using gas chromatography.

The price of the inputs that prevailing during experiment was considered for working out the economics of the various treatment combinations. Cost of cultivation was computed as per treatments. Gross returns were worked out based on the market price of the produce.

Net returns per hectare were calculated by deducting the cost of cultivation from gross returns per hectare. The benefit cost ratio was worked out for different treatments. Fisher method of analysis of variance as given by Panse and Sukhatme (1967) was applied for analysis and interpretation of data. The level of significance used in ' $F$ ' test was at $\mathrm{P}=0.05$ and critical difference (CD) values were worked out wherever ' $F$ ' test was significant.

\section{Results and Discussion}

\section{Growth parameters}

The growth parameters were significantly influenced by planting dates at harvest. Early planting on $5^{\text {th }}$ July 2017 recorded maximum plant height $(73.57 \mathrm{~cm})$ plant spread $(55.93$ $\mathrm{cm}$ ) and maximum number of branches (30.09) compared to the late planting on $5^{\text {th }}$ August 2017 which recorded minimum height $(50.60 \mathrm{~cm})$, spread $(37.09 \mathrm{~cm})$ and minimum branches (20.61). Increased growth parameters with early planting could be attributed to favourable weather conditions which might have influenced the plants to grow taller by increasing cell division and cell elongation Kurian and Sankar (2007). Similar findings were observed by Nilofer et al., (2015) in menthol mint, Sharma and Kanjilal (1999) in pepper mint, Mohammad et al., (2010) in German chamomile, Ram et al., (2010) and Shamaraj et al., (2010) in ashwagandha, Sunil et al., (2011) and Krishna et al., (2014) in kalmegh, Seghatoleslami et al., (2013) in roselle, Kumar et al., (2017) in basil. The reasons for increased

growth parameters during early planting might be due to crop planted on $5^{\text {th }}$ July 2017 did not affected much by heavy rainfall during establishment stage as compared to latter planting as $20^{\text {th }}$ July 2017 and $5^{\text {th }}$ August 2017 planting dates received higher rainfall during establishment and growth stages resulted in slow growth (Fig. 1).

Different cultivars of menthol mint irrespective of planting dates recorded significantly different growth parameters at all stages of crop growth. At harvest among the different cultivars cv. Kushal recorded maximum plant height $(63.19 \mathrm{~cm}), \mathrm{cv}$. 
Saksham recorded minimum plant height $(56.29 \mathrm{~cm})$. At same time, cv. Sambhav recorded maximum plant spread $(49.09 \mathrm{~cm})$ and number of branches (27.12) compared to cv. Saksham which recorded minimum plant spread $(39.47 \mathrm{~cm})$, number of branches (22.90). The increased plant spread and in cv. Sambhav may be due to vigorous growth. Further increased spreading resulted in maximum branches. Change in geographical location or inherent genetic variations could be the major reason for variation in growth parameters among different cultivars. The present results are in contrary to the findings of Nilofer et al., (2015), Lal (2013) where cv. Kosi was superior in terms of growth attributes (Table 1).

Interaction between dates of planting and cultivars had significant influence on growth parameters at harvest. The cv. Kushal planted on $5^{\text {th }}$ July 2017 registered maximum plant height $(78.40 \mathrm{~cm})$, cv. Saksham planted on $5^{\text {th }}$ August 2017 which recorded minimum plant height $(46.80 \mathrm{~cm})$ which might be attributed to synergistic effect of planting date and cultivar which contributed to highest plant height. Among the different interactions, cv. Sambhav on $5^{\text {th }}$ July 2017 (P1V2) registered maximum plant spread $(58.93 \mathrm{~cm})$, number of branches (33.83) compared to cv. Saksham planted on $5^{\text {th }}$ August which recorded minimum plant spread $(32.45 \mathrm{~cm})$, number of branches (18.40). This might be attributed to combined effect of planting date and cultivar that resulted in increased plant spread there by more number of lateral buds leading to more number of branches. These results are in line with findings of Ram et al., (2000), Chauhan et al., (2011) and Sharma (2012) in menthol mint.

\section{Physiological parameters}

Menthol mint planted on $5^{\text {th }}$ July 2017 significantly recorded maximum leaf area
(4833.84 $\left.\mathrm{cm}^{2}\right)$ and total dry matter accumulation (136.13 g/plant) at harvest compared to crop planted on $5^{\text {th }}$ August 2017 which produced minimum leaf area (2377.24 $\mathrm{cm}^{2}$ ) and total dry matter accumulation (104.62 g/plant). Higher leaf area might be due congenial weather conditions during that period which could be attributed to the increased growth expressed by increased number of branches and more plant spread which determines the photosynthetic ability, growth and further dry matter production. Similar findings were observed by Nilofer $e t$ al., (2015) in menthol mint, Solanki and Shaktawat (1999) in isabgol, Agarwal et al., (2004) in ashwagandha, Okosun et al., (2006) in roselle, Singh and Singh (2006) in kalmegh, Shamaraj et al., (2010) in ashwagandha (Table 2).

Physiological parameters were significantly varied with different cultivars. At harvest, among the different cultivars, cv. Sambhav recorded maximum leaf area (4216.67 $\mathrm{cm}^{2} /$ plant) and total dry matter accumulation (147.11 g/plant) compared to cv. Saksham which recorded minimum leaf area (2720.33 $\mathrm{cm}^{2} /$ plant) and total dry matter accumulation (97.02 g/plant). The maximum physiological parameters in cv. Sambhav might be attributed to increased number of branches and more plant spread. However variation in physiological parameters might be due to the varietal characteristics and response of trait to environmental condition. The present results are in contrary to the findings of Chauhan et al., (2011) and Nilofer et al., (2015) where cv. Kosi was superior in terms of growth attributes. Physiological parameter like leaf area varied significantly with the interaction of dates of planting and cultivars at all stages of crop growth. Among the different interactions, cv. Sambhav planted on $5^{\text {th }}$ July 2017 registered maximum leaf area (6035.54 $\mathrm{cm}^{2} /$ plant) compared to cv. Saksham planted on $5^{\text {th }}$ August 2017 which recorded minimum 
leaf area $\left(1639.93 \mathrm{~cm}^{2} /\right.$ plant $)$. Higher leaf area might be due congenial weather conditions during that period which could be attributed to the increased growth expressed by increased number of branches and more plant spread and also due to favourable influence of planting date and cultivars which resulted in maximum leaf area.

\section{Yield and quality parameters}

Menthol mint planted on $5^{\text {th }}$ July 2017 was significantly superior in terms of fresh herbage yield (15.76 t/ha), shade dried herbage yield (11.90 t/ha) and essential oil yield $(95.44 \mathrm{~kg} / \mathrm{ha})$ while minimum fresh herbage yield (9.13 t/ha), shade dried herbage yield (8.23 t/ha) and essential oil yield (52.71 $\mathrm{kg} / \mathrm{ha}$ ) was recorded by planting on $5^{\text {th }}$ August 2017.

This might be due to increased leaf area which might have produced and translocated more photosynthates resulting in better plant growth in terms of plant height, plant spread and number of branches resulting in higher fresh herb, shade dried herb and essential oil yield. These findings are in agreement to those reported by Sharma (2012), Nilofer et al., (2015) in menthol mint, Sarma and Kanjilal (2000) in patchouli, Mann and Vyas (2001) in isabgol, Castro et al., (2004) in roselle, Jyoti et al., (2009) in coleus, Sadeghi et al., (2009) in basil, Shamsi (2009) in milk thistle. Krishna et al., (2014) in kalmegh.

Oil content was significantly influenced by dates of planting at all stages of growth. At harvest, early planting on $5^{\text {th }}$ July 2017 recorded maximum oil content $(0.79 \%)$ compared to the late planting on $5^{\text {th }}$ August $2017(0.63 \%)$. It was due to favourable weather conditions required for crop i.e. optimum temperature and relative humidity and these factors enhanced the ratio of leaves to stem resulting in higher oil content. Lower oil content in delayed planting was on account of heavy rains during maturity time, which ruptured and washed off oil glands of leaves. The results are in line with those findings by Sharma (2012) and Nilofer et al., (2015) in menthol mint. The influence of planting dates was found nonsignificant with respect to menthol content.

Different cultivars of menthol mint irrespective of planting dates recorded significantly different yield parameters. At harvest, cv. Sambhav recorded maximum fresh herb yield (13.53 t/ha), shade dried herbage yield (11.10 t/ha), oil content $(0.78$ $\%)$ and essential oil yield $(88.48 \mathrm{~kg} / \mathrm{ha})$ compared to cv. Saksham which recorded minimum fresh herb yield $(9.60 \mathrm{t} / \mathrm{ha})$, shade dried herbage yield (7.84 t/ha), oil content $(0.63 \%)$ and essential oil yield $(51.37 \mathrm{~kg} / \mathrm{ha})$. The average menthol content of menthol mint was significantly influenced by the cultivars. Cultivar Sambhav recorded maximum menthol content (72.06 \%), whereas minimum was noticed in $\mathrm{cv}$. Himalaya (70.41 $\%)$.

The possible reason for the increase in fresh herb weight could be due to higher growth attributes viz., plant spread and number of branches, physiological attributes like leaf area and total dry matter accumulation there by more fresh and shade dried herb weight which leads to increased oil content and essential oil yield. Majority of the workers had the idea that yield potential was varietal character. The present results are in contrary to the findings of Kumar et al., (2000), Chauhan et al., (2011), Lal (2013) and Nilofer et al., (2015), where cv. Kosi was superior in terms of yield and quality attributes. The effect of interaction between cultivars and planting date found nonsignificant on yield and quality parameters (Table 3 and 4). 
Table.1 Influence of dates of planting on growth parameters of menthol mint (Mentha arvensis L.) cultivars at harvest (120 DAP)

\begin{tabular}{|c|c|c|c|c|c|c|c|c|c|c|c|c|c|c|c|c|c|c|}
\hline \multicolumn{19}{|c|}{ Growth parameters } \\
\hline \multirow[t]{2}{*}{ Treatments } & \multicolumn{6}{|c|}{ Plant height $(\mathbf{c m})$} & \multicolumn{6}{|c|}{ Plant spread $(E-W$ and N-S) $(\mathrm{cm})$} & \multicolumn{6}{|c|}{ Number of branches } \\
\hline & $V_{1}$ & $\mathbf{V}_{2}$ & $\mathbf{V}_{3}$ & $\mathbf{V}_{4}$ & $\mathbf{V}_{5}$ & Mean & $V_{1}$ & $\mathbf{V}_{2}$ & $\mathbf{V}_{3}$ & $\mathbf{V}_{4}$ & $\mathbf{V}_{5}$ & Mean & $V_{1}$ & $\mathbf{V}_{2}$ & $\mathbf{V}_{3}$ & $\mathbf{V}_{4}$ & $\mathbf{V}_{5}$ & Mean \\
\hline $\mathbf{P}_{1}$ & 72.87 & 78.40 & 75.33 & 69.80 & 71.47 & 73.57 & 55.92 & 58.02 & 58.93 & 50.40 & 56.40 & 55.93 & 28.17 & 33.03 & 33.83 & 27.13 & 28.30 & 30.09 \\
\hline $\mathbf{P}_{2}$ & 50.07 & 57.97 & 56.10 & 52.27 & 51.20 & 53.52 & 38.22 & 46.57 & 47.53 & 35.58 & 38.65 & 41.31 & 23.40 & 24.83 & 25.50 & 23.17 & 24.60 & 24.30 \\
\hline $\mathbf{P}_{3}$ & 47.37 & 53.20 & 52.73 & 46.80 & 52.90 & 50.60 & 34.90 & 39.43 & 40.83 & 32.45 & 37.85 & 37.09 & 20.27 & 21.30 & 22.03 & 18.40 & 21.07 & 20.61 \\
\hline Mean & 56.77 & 63.19 & 61.38 & 56.29 & 58.52 & & 43.01 & 48.00 & 49.09 & 39.47 & 44.30 & & 23.94 & 26.38 & 27.12 & 22.90 & 24.65 & \\
\hline \multicolumn{19}{|c|}{ For comparison of mean } \\
\hline & & \multicolumn{3}{|c|}{ S.Em \pm} & \multicolumn{2}{|c|}{ CD @ $5 \%$} & \multicolumn{3}{|c|}{ S.Em \pm} & \multicolumn{3}{|c|}{ CD@ $5 \%$} & \multicolumn{3}{|c|}{ S.Em \pm} & \multicolumn{3}{|c|}{ CD @ $5 \%$} \\
\hline \multicolumn{2}{|c|}{ Planting dates(P) } & \multicolumn{3}{|c|}{$\begin{array}{l}0.76 \\
0.64\end{array}$} & \multicolumn{2}{|c|}{2.97} & \multicolumn{3}{|c|}{$\begin{array}{l}0.71 \\
0.60\end{array}$} & \multicolumn{3}{|c|}{2.78} & \multicolumn{3}{|c|}{0.35} & \multicolumn{3}{|c|}{1.39} \\
\hline \multicolumn{2}{|c|}{$V$ at same level of $P$} & \multicolumn{3}{|c|}{1.11} & \multirow{2}{*}{\multicolumn{2}{|c|}{20.54}} & \multicolumn{3}{|c|}{1.04} & \multicolumn{2}{|r|}{1.75} & & & 0.59 & & \multicolumn{3}{|c|}{1.72} \\
\hline \multicolumn{2}{|c|}{$\begin{array}{l}P \text { at same or different } \\
\text { level of } V\end{array}$} & \multicolumn{2}{|r|}{6.25} & & & & \multicolumn{3}{|c|}{5.83} & \multicolumn{3}{|c|}{19.19} & & 3.17 & & & 10.24 & \\
\hline
\end{tabular}

Table.2 Influence of dates of planting on physiological parameters of menthol mint (Mentha arvensis L.) cultivars at harvest (120 DAP)

\begin{tabular}{|c|c|c|c|c|c|c|c|c|c|c|c|c|}
\hline \multirow[t]{2}{*}{ Treatments } & \multicolumn{6}{|c|}{ Leaf area $\left(\mathrm{cm}^{2} /\right.$ plant $)$} & \multicolumn{6}{|c|}{ Total dry matter accumulation (g/plant) } \\
\hline & $\mathbf{V}_{1}$ & $\mathbf{V}_{2}$ & $\mathbf{V}_{3}$ & $\mathbf{V}_{4}$ & $\mathbf{V}_{5}$ & Mean & $\mathbf{V}_{1}$ & $\mathbf{V}_{2}$ & $\mathbf{V}_{3}$ & $\mathbf{V}_{4}$ & $\mathbf{V}_{5}$ & Mean \\
\hline $\mathbf{P}_{1}$ & 4413.32 & 5314.74 & 6035.54 & 3914.34 & 4491.29 & 4833.84 & 133.33 & 137.67 & 161.00 & 111.33 & 137.33 & 136.13 \\
\hline $\mathbf{P}_{2}$ & 2879.85 & 3212.97 & 3855.40 & 2606.72 & 3145.71 & 3140.13 & 102.33 & 144.33 & 147.67 & 97.40 & 100.67 & 118.48 \\
\hline $\mathbf{P}_{3}$ & 2338.76 & 2714.57 & 2759.09 & 1639.93 & 2433.88 & 2377.24 & 88.77 & 130.00 & 132.67 & 82.33 & 89.33 & 104.62 \\
\hline Mean & 3210.64 & 3747.42 & 4216.67 & 2720.33 & 3356.96 & & 108.14 & 137.33 & 147.11 & 97.02 & 109.11 & \\
\hline \multicolumn{13}{|c|}{ For comparison of mean } \\
\hline & & & \multicolumn{2}{|c|}{ S.Em \pm} & \multicolumn{2}{|c|}{ CD@5\% } & \multicolumn{3}{|c|}{ S.Em \pm} & \multicolumn{3}{|c|}{ CD@5\% } \\
\hline \multicolumn{3}{|c|}{ Varieties (V) } & \multicolumn{2}{|c|}{102.48} & \multicolumn{2}{|c|}{299.12} & \multicolumn{3}{|c|}{3.58} & \multicolumn{3}{|c|}{10.46} \\
\hline \multicolumn{3}{|c|}{$V$ at same level of $P$} & \multicolumn{2}{|c|}{177.50} & \multicolumn{2}{|c|}{518.09} & \multicolumn{3}{|c|}{6.21} & \multicolumn{3}{|c|}{ NS } \\
\hline \multicolumn{3}{|c|}{$P$ at same or different level of $V$} & \multicolumn{2}{|c|}{825.87} & \multicolumn{2}{|c|}{2473.92} & \multicolumn{3}{|c|}{33.85} & \multicolumn{3}{|c|}{ NS } \\
\hline
\end{tabular}

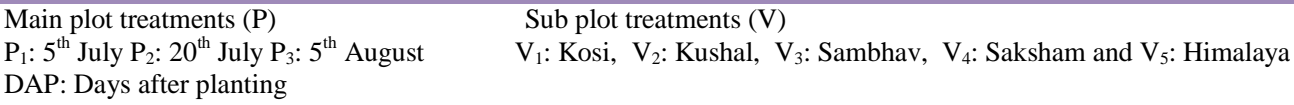


Table.3 Influence of dates of planting on yield parameters of menthol mint (Mentha arvensis L.) cultivars at harvest (120 DAP)

\begin{tabular}{|c|c|c|c|c|c|c|c|c|c|c|c|c|}
\hline \multirow[t]{2}{*}{ Treatments } & \multicolumn{6}{|c|}{ Fresh herbage yield (t/ha) } & \multicolumn{6}{|c|}{ Shade dried herbage yield (t/ha) } \\
\hline & $V_{1}$ & $\mathbf{V}_{2}$ & $\mathbf{V}_{3}$ & $\mathbf{V}_{4}$ & $V_{5}$ & Mean & $V_{1}$ & $\mathbf{V}_{2}$ & $\mathbf{V}_{3}$ & $\mathbf{V}_{4}$ & $V_{5}$ & Mean \\
\hline $\mathbf{P}_{1}$ & 15.51 & 16.58 & 17.98 & 13.55 & 15.16 & 15.76 & 11.43 & 12.62 & 13.77 & 10.22 & 11.49 & 11.90 \\
\hline $\mathbf{P}_{2}$ & 11.21 & 12.50 & 12.70 & 8.26 & 9.91 & 10.92 & 8.96 & 10.00 & 10.85 & 6.60 & 7.78 & 8.83 \\
\hline $\mathbf{P}_{3}$ & 8.61 & 9.24 & 9.91 & 6.97 & 10.92 & 9.13 & 7.82 & 8.29 & 8.69 & 6.70 & 9.65 & 8.23 \\
\hline Mean & 11.78 & 12.77 & 13.53 & 9.60 & 12.00 & & 9.40 & 10.30 & 11.10 & 7.84 & 9.64 & \\
\hline \multicolumn{13}{|c|}{ For comparison of mean } \\
\hline & & & \multicolumn{2}{|c|}{ S.Em \pm} & \multicolumn{2}{|c|}{ CD@5\% } & \multicolumn{3}{|c|}{ S.Em \pm} & \multicolumn{3}{|c|}{ CD@5\% } \\
\hline \multicolumn{3}{|c|}{ Planting dates(P) } & \multicolumn{2}{|c|}{0.36} & \multicolumn{2}{|c|}{1.43} & \multicolumn{3}{|c|}{0.42} & \multicolumn{3}{|c|}{1.67} \\
\hline \multicolumn{3}{|l|}{ Varieties (V) } & \multicolumn{2}{|c|}{0.35} & \multicolumn{2}{|c|}{1.03} & \multicolumn{3}{|c|}{0.29} & \multicolumn{3}{|c|}{0.84} \\
\hline \multicolumn{3}{|c|}{$\mathrm{V}$ at same level of $\mathrm{P}$} & \multicolumn{2}{|c|}{0.61} & \multicolumn{2}{|c|}{ NS } & \multicolumn{3}{|c|}{0.50} & \multicolumn{3}{|c|}{ NS } \\
\hline \multicolumn{3}{|c|}{$P$ at same or different level of $V$} & \multicolumn{2}{|c|}{3.29} & \multicolumn{2}{|c|}{ NS } & \multicolumn{3}{|c|}{3.09} & \multicolumn{3}{|c|}{ NS } \\
\hline
\end{tabular}

Main plot treatments $(\mathrm{P})$

$P_{1}: 5^{\text {th }}$ July $P_{2}: 20^{\text {th }}$ July $\mathrm{P}_{3}: 5^{\text {th }}$ August

$\mathrm{V}_{1}$ : Kosi, $\mathrm{V}_{2}$ : Kushal, $\mathrm{V}_{3}$ : Sambhav, $\mathrm{V}_{4}$ : Saksham and $\mathrm{V}_{5}$ : Himalaya

DAP: Days after planting

Table.4 Influence of dates of planting on oil content, oil yield and menthol content of menthol mint (Mentha arvensis L.) cultivars at harvest (120 DAP)

\begin{tabular}{|c|c|c|c|c|c|c|c|c|c|c|c|c|c|c|c|c|c|c|}
\hline \multirow[t]{2}{*}{ Treatments } & \multicolumn{6}{|c|}{ Oil content (\%) } & \multicolumn{6}{|c|}{ Oil yield (kg/ha) } & \multicolumn{6}{|c|}{ Menthol content (\%) } \\
\hline & $\mathbf{V}_{1}$ & $\mathbf{V}_{2}$ & $\mathbf{V}_{3}$ & $\mathbf{V}_{4}$ & $V_{5}$ & Mean & $V_{1}$ & $\mathbf{V}_{2}$ & $\mathbf{V}_{3}$ & $\mathbf{V}_{4}$ & $V_{5}$ & Mean & $\mathbf{V}_{1}$ & $\mathbf{V}_{2}$ & $\mathbf{V}_{3}$ & $\mathbf{V}_{4}$ & $V_{5}$ & Mean \\
\hline $\mathbf{P}_{1}$ & 0.77 & 0.86 & 0.90 & 0.66 & 0.78 & 0.79 & 89.29 & 108.42 & 121.59 & 67.76 & 90.15 & 95.44 & 71.87 & 71.20 & 72.92 & 71.42 & 71.46 & 71.77 \\
\hline $\mathbf{P}_{2}$ & 0.70 & 0.72 & 0.77 & 0.65 & 0.67 & 0.70 & 63.44 & 69.27 & 83.89 & 45.14 & 54.07 & 63.16 & 71.11 & 70.52 & 71.41 & 70.63 & 70.20 & 70.77 \\
\hline $\mathbf{P}_{3}$ & 0.62 & 0.66 & 0.69 & 0.60 & 0.61 & 0.63 & 49.25 & 54.78 & 59.96 & 41.21 & 58.35 & 52.71 & 70.43 & 70.92 & 71.85 & 70.75 & 69.58 & 70.70 \\
\hline Mean & 0.69 & 0.74 & 0.78 & 0.63 & 0.68 & & 67.32 & 77.49 & 88.48 & 51.37 & 67.52 & & 71.13 & 70.88 & 72.06 & 70.93 & 70.41 & \\
\hline
\end{tabular}

For comparison of mean

\begin{tabular}{|c|c|c|c|c|c|c|}
\hline & S.Em \pm & CD@5\% & S.Em \pm & CD@5\% & S.Em \pm & CD@5\% \\
\hline Planting dates(P) & 0.02 & 0.07 & 3.31 & 12.99 & 0.32 & NS \\
\hline Varieties (V) & 0.01 & 0.03 & 2.15 & 6.29 & 0.27 & 0.79 \\
\hline$V$ at same level of $P$ & 0.02 & NS & 3.73 & NS & 0.47 & NS \\
\hline $\begin{array}{l}P \text { at same or } \\
\text { different level of } V\end{array}$ & 0.12 & NS & 23.50 & NS & 2.62 & NS \\
\hline
\end{tabular}


Table.5 Economics of cultivation as influenced by interaction of dates of planting and cultivars of menthol mint (Mentha arvensis L.)

\begin{tabular}{|c|c|c|c|c|}
\hline Treatments & $\begin{array}{c}\text { Cost of cultivation } \\
(\square / \mathrm{ha})\end{array}$ & $\begin{array}{c}\text { Gross returns } \\
(\square / \mathrm{ha})\end{array}$ & $\begin{array}{l}\text { Net returns } \\
\text { ( } \square / \mathrm{ha})\end{array}$ & $\begin{array}{l}\text { B:C } \\
\text { Ratio }\end{array}$ \\
\hline $\mathbf{P}_{1} \mathbf{V}_{1}$ & $50,210.40$ & $1,07,148.00$ & $56,936.60$ & 2.13 \\
\hline $\mathbf{P}_{1} \mathbf{V}_{2}$ & $51,281.00$ & $1,30,104.00$ & $78,822.00$ & 2.53 \\
\hline$P_{1} V_{3}$ & $52,680.40$ & $1,45,908.00$ & $93,226.60$ & 2.76 \\
\hline $\mathbf{P}_{1} \mathbf{V}_{4}$ & $48,250.00$ & $81,312.00$ & $33,060.60$ & 1.68 \\
\hline$P_{1} V_{5}$ & $49,860.00$ & $1,08,180.00$ & $58,319.00$ & 2.16 \\
\hline $\mathbf{P}_{2} \mathbf{V}_{1}$ & $45,910.00$ & $76,128.00$ & $30,217.00$ & 1.65 \\
\hline $\mathbf{P}_{2} \mathbf{V}_{2}$ & $47,200.00$ & $83,124.00$ & $35,923.00$ & 1.76 \\
\hline $\mathbf{P}_{2} \mathbf{V}_{3}$ & $47,400.00$ & $1,00,668.00$ & $53,267.00$ & 2.12 \\
\hline $\mathbf{P}_{2} \mathbf{V}_{4}$ & $42,960.00$ & $54,168.00$ & $11,207.00$ & 1.26 \\
\hline$P_{2} V_{5}$ & $44,610.00$ & $64,884.00$ & $20,273.00$ & 1.45 \\
\hline $\mathbf{P}_{3} \mathbf{V}_{1}$ & $43,310.00$ & $59,100.00$ & $15,789.00$ & 1.36 \\
\hline $\mathbf{P}_{3} \mathbf{V}_{2}$ & $43,940.00$ & $65,736.00$ & $21,795.00$ & 1.49 \\
\hline $\mathbf{P}_{3} \mathbf{V}_{3}$ & $44,610.00$ & $71,952.00$ & $27,341.00$ & 1.61 \\
\hline $\mathbf{P}_{3} \mathbf{V}_{4}$ & $41,670.00$ & $49,452.00$ & $7,781.00$ & 1.18 \\
\hline $\mathbf{P}_{3} \mathbf{V}_{5}$ & $45,620.00$ & $70,020.00$ & $24,399.00$ & 1.53 \\
\hline $\begin{array}{l}\text { Main plot treatments }(\mathrm{P}) \\
\mathrm{P}_{1}: 5^{\text {th }} \text { July } \\
\mathrm{P}_{2}: 20^{\text {th }} \text { July } \\
\mathrm{P}_{3}: 5^{\text {th }} \text { August }\end{array}$ & $\begin{array}{l}\text { Sub plot treatn } \\
\mathrm{V}_{1}: \text { Kosi } \\
\mathrm{V}_{2}: \text { Kushal } \\
\mathrm{V}_{3}: \text { Sambhav } \\
\mathrm{V}_{4}: \text { Saksham } \\
\mathrm{V}_{5}: \text { Himalaya }\end{array}$ & $s(V)$ & & \\
\hline
\end{tabular}

Fig.1 Weekly meteorological data recorded during experiment

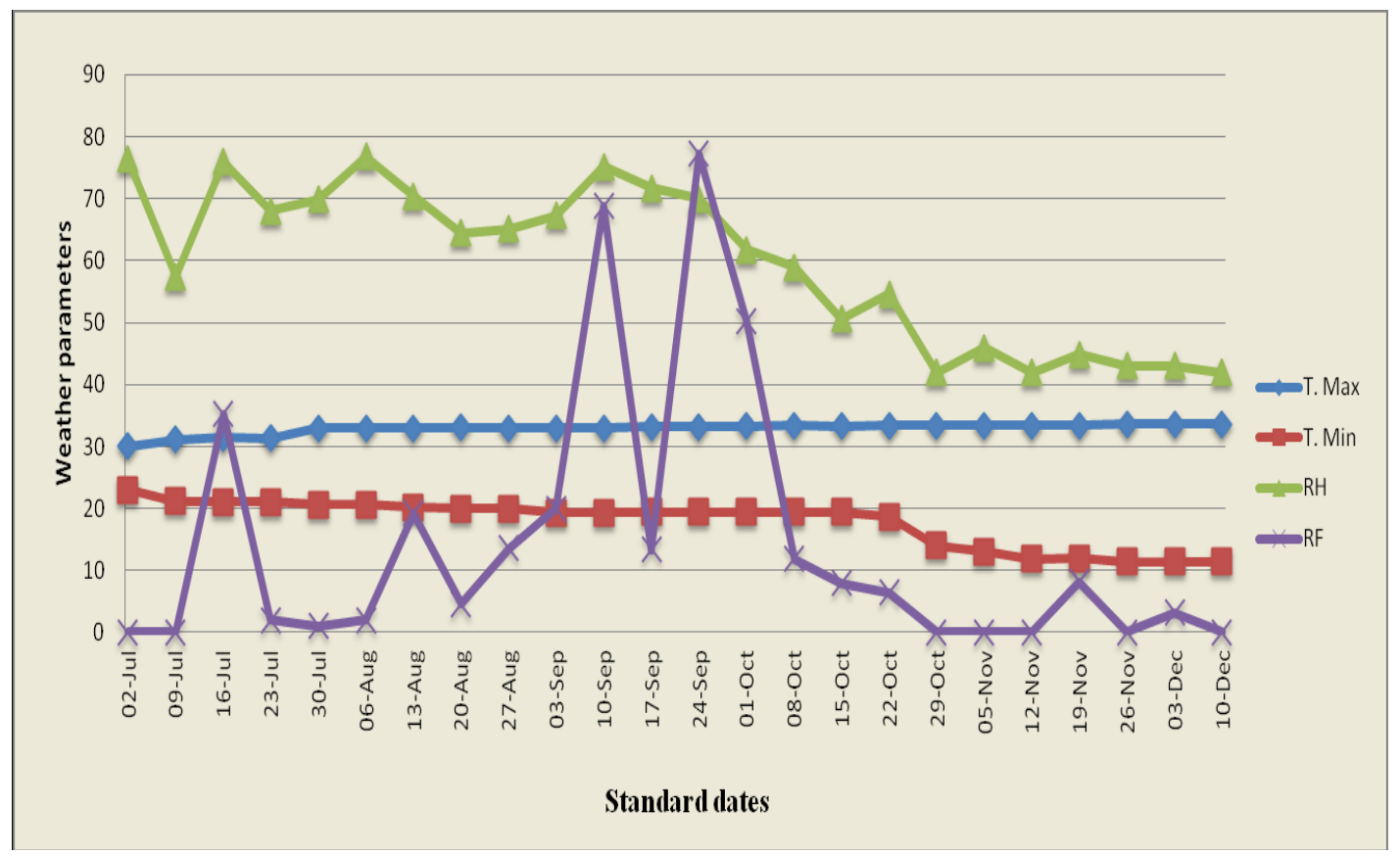




\section{Economics}

The maximum cost of cultivation ( $\square$ $52,680.40 / \mathrm{ha}), \quad$ gross returns ( $\square$ 1,45,908.00/ha), net returns ( $\square$ 93,226.60/ha) and B: C ratio (2.76) were obtained when cv. Sambhav planted on 5th July 2017, while minimum cost of cultivation ( $\square$ 41,670.00/ha), gross returns ( $\square$ 49,452.00/ha), net returns ( $\square 7,781.00 / \mathrm{ha}$ ) and B: C ratio (1.18) were recorded when cv. Saksham planted on $5^{\text {th }}$ August 2017. This was because of the highest production of herbage yield which resulted in increased essential oil yield leads to maximum net returns and B: C ratio. Similar results were also reported by Nilofer (2015) in menthol mint (Table 5).

In conclusion, during kharif season, planting of menthol mint cv. Sambhav on $5^{\text {th }}$ July is advisable to obtain maximum herbage, oil yield, net returns and $\mathrm{B}$ : $\mathrm{C}$ ratio under northern dry zone of Karnataka.

\section{References}

Agarwal, M., Singh, P. and Agarwal, M. K., 2004, Effect of sowing dates and spacing on yield attributes and root yield of ashwagandha (Withania somnifera). J. Med. Arom. Plant Sci., 26: 473-474.

Castro, N. E. A., de Pinto, Cardoso, J. E. B. P., das, M., Morais, G., de Bertolucci, A. R., Silva, S. K. V. and da Delufilho, N., 2004, Planting time for maximization of yield of vinegar plant calyx (Hibiscus sabdariffa L.). Ciencia e Agrotecnologia., 28(3): 542551.

Chauhan, R. K., Anwar, M., Chand, S. and Patra, D. D., 2011, Influence of different dates of planting on growth, herb, oil yield and quality of essential oil of Menthol mint (Mentha arvensis) in North Indian Plain. Arch. Agron \& Soil Sci., 58(2): 223-232.

Jyoti, N., Shrivastva, A., Thakur, A. and Agarwal, V. K., 2009, Effect of date of planting on yield and biochemical changes in Coleus forskohlii. Biomed., 4(2):118-122.

Krishna, M., Pandey, S. T., Kumar, A. and Dhyani, V. C., 2014, Effect of date of nursery sowing and planting geometry on growth and dried herb yield of kalmegh (Andrographis paniculata). Int. J. Basic and Appl. Agric. Res., 12(1): 1-4.

Kumar, R., Neetu, Singh, V. R., Upadhyay, R. K. and Tiwai, A. K., 2017, Effect of sowing dates and planting distance on growth, oil and seed yield of sweet basil (Ocimum basilicum L.). Int J. Trop Agric., 35(1): 165-169.

Kumar, S., Bahl, J. R., Bansal, R. P., Kukreja, A. K., Garg, S. N., Naqvi, A. A., Luthra, R. and Sharma, S., 2000, Profiles of the essential oils of Indian menthol mint Mentha arvensis cultivars at different stages of crop growth in northern plains. J. Med. Arom. Plant Sci., 22(1): 774-786.

Kurian, A. and Shankar, A. M., 2007, Medicinal Plants. New India Publishing Agency- New Delhi.

Lal, R. K., 2013, Adaptability patterns and stable cultivar selection in menthol mint (Mentha arvensis L.). Ind. Crops and Prod., 50: 176-181.

Mann, P. S and Vyas, A. K., 2001, Effect of sowing dates and nitrogen levels on yield, quality and net returns of blonde psyllium (Plantago ovata forsk.). Annal Agric Res., New Series 22(3): 425-428.

Mohammad, R., Hamid, S., Adam, A., Norbet, K. and Patrick, V. D., 2010, Effect of planting

date and seedling age on agro- morphological characteristics, essential oil content 
and composition of German chamomile (Matricaria chamomilla L.) grown in Belgium. Ind. Crops Prod., 31: 145-152.

Nilofer, Singh, S., Singh, K. A., Singh, H. N. and Kalra, A., 2015, Effect of weather conditions on growth, yield and quality of Menthol mint (Mentha arvensis L.) cultivars transplanted in different years on different dates under sub-tropical climate of North India. Indian J. Agric. Res., 6(2): 82-88.

Okosun, L. A., Magaji, M. D. and Yakubu, A. I., 2006, Effect of sowing date and planting distance on growth and yield of two cultivars of roselle (Hibiscus sabdariffa var. sabdariffa). J. Plant Sci., 1(4): 297-305.

Panse, V. G., and Sukhatme, P. V., 1967, Statistical Methods for Agricultural Workers, ICAR, New Delhi. pp. 152174.

Ram, D., Vishwanath, Chandra, R. and Kumar, R., 2010, Effect of time and method of sowing on growth and root yield of ashwagandha (Withania somnifera). Res. J. Agric. \& Biol. Sci., 6(4): 548-551.

Ram, M., Ram, D., Singh, S., Roy, S. K. and Kumar, S., 2000, Effect of planting time on the growth and essential oil yield in different varieties of menthol mint (Mentha arvensis L.). J. Med. Arom. Plant Sci., 22(4): 400-403.

Sadeghi, S., Rahnavaed, A. and Ashrafi, Z. Y., 2009, Effect of plant density and sowing date on yield of basil (Ocimum basilicum L.) in Iran. J. Agric. Tech., 5(2): 413-422.

Sarma, P. C. and Kanjilal, P. B., 2000, Effect of planting time and row spacing on growth, yield and quality of patchouli (Pogostemon patchouli). Adv in Plant Sci., 13(1): 201- 204.

Seghatoleslami, M. J., Mousavi, S. G. and Barzgaran, T., 2013, Effect of irrigation and planting date on morpho-physiological traits and yield of roselle (Hybiscus sabdariffa). J. Animal and Plant Sci., 23(1): 256-260.

Shamaraj, Chandranath, H. T., Pujari, B. T. and Halepyati., 2010, Influence of planting dates and stage of harvesting on root yield, root yield parameters and quality of ashwagandha. Karnataka J. Agric. Sci., 23(2): 339340.

Shamsi, K., 2009, Effect of planting date and density on the yield and yield components of milk thistle (Silybium marianum L.). J. Appl. Biosci., 16(6): 862-863.

Sharma, P. C. and Kanjilal P. B., 1999, Effect of planting time and density on yield and quality of peppermint (Mentha piperata L.) under sub-tropical condition. Anc. Sci. Life., 18 (3\&4): 284-289.

Sharma, S., 2012, Effect of dates of transplanting on the growth and oil yield of menthol mint (Mentha arvensis L.). Scholarly J. Agric. Sci., 2(7): 130-132.

Singh, S, Singh, A. K. and Singh, M., 2008, Weather and aromatic crops. MAPs Dew., 4(3): 41-44.

Singh, S., 2005, Mentha and mansoon, MAPs Dew., 1(1): 16-17.

Singh, V. and Singh, R. K., 2006, Effect of season, time of planting and plant density on the growth, yield and andrographolide content of kalmegh (Andrographis paniculata Nees.) under north Indian condition. Int. J. Plant Sci., 1(1):6-9.

Solanki, N. S. and Shaktawat, R. R. S., 1999, Effect of date of sowing and nitrogen on growth and yield of isabgol (Plantago ovata Forsk.). Indian J. Agric. Sci., 69(7): 528-529.

Sunil, J. N., Gangadharappa, P. M., Kattimani, Hegde, L. N., Hegde, N. K. 
and Mastiholi, A. B., 2011, Effect of dates of planting and nitrogen levels on growth and yield of kalmegh. J. Asian Hort., 7(4): 221-226.
Varshney, S. C., 2011, Future of natural menthol industry. Indian Perfumer., 54: $12-14$.

\section{How to cite this article:}

Shwetha Desai, T.N. Pushpa, D. Srikantaprasad, V. Kantharaju, I.B. Biradar and Hiremath, J.S. 2019. Influence of Different Planting Dates on Growth, Yield and Quality of Menthol Mint (Mentha arvensis L.) Cultivars during Kharif Season. Int.J.Curr.Microbiol.App.Sci. 8(06): 468478. doi: https://doi.org/10.20546/ijcmas.2019.806.053 